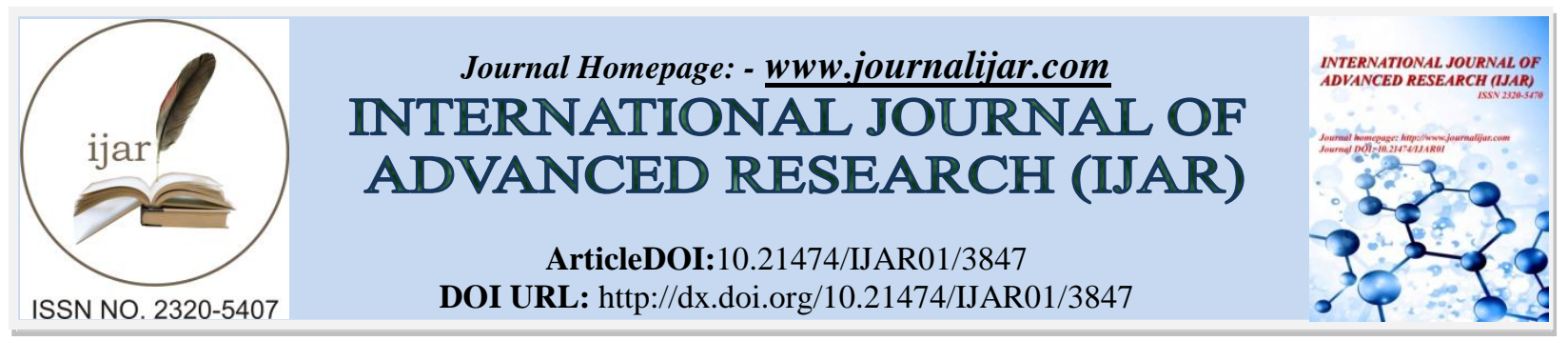

RESEARCH ARTICLE

\title{
ASSESSMENT OF WATER QUALITY INDEX (WQI) IN KEERAT SAGAR POND AT MAHOBA DISTRICT OF UTTAR PRADESH, INDIA.
}

Dr. Manoj Kumar Gupta ${ }^{1}$, Umesh Kumar Mishra ${ }^{2}$, Praveen Kumar ${ }^{2}$ and Dharmendra Kumar ${ }^{3}$

1. Department of Zoology, DVC College, Orai, Jalaun U.P.285001,

2. Department of Zoology, Bipin Bihari P.G. College, Bundelkhand University, Jhansi 284002 U.P.

3. Department of Zoology, Bundelkhand University, Jhansi- 284128, U.P

\section{Manuscript Info}

(1...........................

Manuscript History

Received: 04 February 2017

Final Accepted: 01 March 2017

Published: April 2017

Key words:-

Physico-Chemical Parameters, Keerat

Sagar Pond, Mahoba.

\section{Abstract}

The purpose of this research was to investigate the water quality index of Keerat Sagar pond at Mahoba district of Uttar Pradesh by using physico-chemical parameters. The samples were collected throughout the year from December (2002) to November (2003), and various hydrological parameters such as temperature, turbidity, $\mathrm{pH}$, carbonate, bicarbonate, total alkalinity, chloride, dissolved oxygen and free carbon di-oxide were analyzed from the pond. The results obtained from all these parameters indicate that all the factors were within the permissible limits and the pond is suitable for the aquatic standing crop such as fish, prawn and shrimps culture.

Copy Right, IJAR, 2017,. All rights reserved.

\section{Introduction:-}

Keerat Sagar pond (1060-1100 AD) was established by $13^{\text {th }}$ king Kirtiverman in Mahoba district which is situated at western side of the city. Its geolocation is $25^{\circ} 01^{\prime} 30 \mathrm{~N}-25^{0} 39^{\prime} 40 \mathrm{~N}$ latitude and $79^{0} 15^{\prime} 00^{\prime}$ E- 80 $80^{\circ} 10^{\prime} 30^{\prime} \mathrm{N}$ Longitude. The pond was created in $1060 \mathrm{BC}$ for the purpose of collection of rain water and recharging of ground water but in recent decades this pond also is utilized for culturing many faunal activities by several local authorities and villagers.

Water is the prime need of all the life activities. It supports aquatic as well as human ecosystem. The hydrobiological relationship reveals the healthy ecosystem. Water Quality is an important factor to judge environment changes, which are strongly associated with social and economic development. Due to increase in population, Urbanization and industrialization in the past century have resulted in increased domestic and industrial effluent being discharged into the aquatic system (Ajmal et al 1988, Ekpo et.al.1999)

The evaluation of water in the developing countries has become a critical issue in recent years, especially due to the concern that fresh water will be scarce in near future (Darapu et al, 2011). The healthy aquatic ecosystem is depends on the physico-chemical characteristics of water (Venkatesharaju et.al.2010).

\section{Material and Methods:- \\ Study Area:- \\ Keerat Sagar Pond.}


Sample Collection:- Water samples were collected from the pond during December 2002 to November 2003 in every month with the help of water sampling Polythene bottle. Some parameters tested at the time of samples collection while others were carried out in departmental laboratory for Physico-chemical estimation.

Sites Every region of the pond (inlet, outlet, bank area and middle region) were selected for sample collection.

Experimental Analysis:- Various Physico-chemical parameters were analyzed by using standard method described by Trivedi and Goyal (1986), Kodarkar (1992), APHA (2005) and Jain \& Jain (2007).

Water Temperature:- water samples were analyzed with the help of mercury thermometer.

Turbidity: Turbidity was recorded by Systronics Nephloturbidity meter and expressed as NTU.

pH:- It was measured at the site by $\mathrm{BDH}$ narrow range $\mathrm{pH}$ strips by compared it with the color disk.

Carbonate and Bicarbonate:- Bicarbonate. $0.02 \mathrm{~N}$ (N/50), sulphuric acid standard $0.02 \mathrm{~N}(\mathrm{~N} / 50) \mathrm{Na}_{2} \mathrm{CO}_{3}$ and phenopthlene alkalinity regents were used in for carbonate estimation.

Phenopthlene alkalinity $\mathrm{mg} / \mathrm{l}=$ num of $\mathrm{ml}$ of $0.02 \mathrm{~N} \mathrm{H}_{2} \mathrm{SO}_{4}$ Used X 10

Bicarbonate alkalinity was determined by procedure (Vide supra) with methyl orange as indicator.

Bicarbonate alkalinity $\mathrm{mg} / \mathrm{l}=\mathrm{No}$ of $\mathrm{ml} 0.02 \mathrm{~N} \mathrm{H}_{2} \mathrm{SO}_{4}$ used X 10

Dissolved Oxygen (DO):- Dissolved oxygen was estimated by Winkler's method using alsterberg azide modification.

Carbon di-oxide:- Estimated at the sampling site. N/44 NaOH, 4 gm of AR quality $\mathrm{NaOH}$ dissolved in $1 \mathrm{~L}$ of distilled water, which give $0.1 \mathrm{~N} \mathrm{NaoH}$. Standardized this solution with $0.1 \mathrm{Na} 2 \mathrm{SO} 4$ using phenolphthalein indicator. $100 \mathrm{ml}$ of this solution is diluting to $440 \mathrm{ml}$ gives $\mathrm{N} / 44 \mathrm{NaOH}$.

\section{Discussion and Result:-}

\section{Physical Parameters:-}

Water Temperature:- It is the one of the most essential factor for influence the aquatic life. It was ranged from 14.6 to $32.5^{\circ} \mathrm{C}$ (Table-A, Graph-1). Minimum and maximum temperatures were recorded in the month of January and June respectively. Similar records were also recorded by Anand et al (2014). Higher water temperature in summer is due to the low water level and low temperature in January is due to the water cycle.

Turbidity It was ranged from 15.20 to 69.25 NTU (Table-A, Graph-1). The higher value of turbidity was observed during monsoon period due to high wind velocity and silting respectively while the lower value of turbidity was recorded in January due to lack of silt and low wind velocity. A similar trend of fluctuation was also observed by Shimpi,B. et al (2011).

Table A:- Monthly Recorded Chemical Parameters in Keerat Sagar Pond (2002-2003)

\begin{tabular}{|c|c|c|c|}
\hline Month & Water Temperature $\left({ }^{\circ} \mathrm{C}\right)$ & Turbidity (NTU) & $\mathrm{pH}$ \\
\hline Dec. & 15.9 & 18.50 & 8.1 \\
\hline Jan. & 14.6 & 15.20 & 8.2 \\
\hline Feb. & 18.6 & 16.30 & 8.0 \\
\hline Mar. & 22.7 & 16.20 & 8.0 \\
\hline Apr. & 26.4 & 20.80 & 8.1 \\
\hline May & 30.5 & 21.00 & 8.1 \\
\hline Jun. & 32.5 & 29.50 & 8.0 \\
\hline Jul. & 30.6 & 69.25 & 7.9 \\
\hline Aug. & 28.2 & 69.25 & 7.5 \\
\hline Sept. & 27.0 & 58.50 & 7.8 \\
\hline Oct. & 24.8 & 33.80 & 7.7 \\
\hline Nov. & 20.1 & 29.00 & 8.0 \\
\hline
\end{tabular}


Graph 1:- Monthly Variations in Physical Parameters

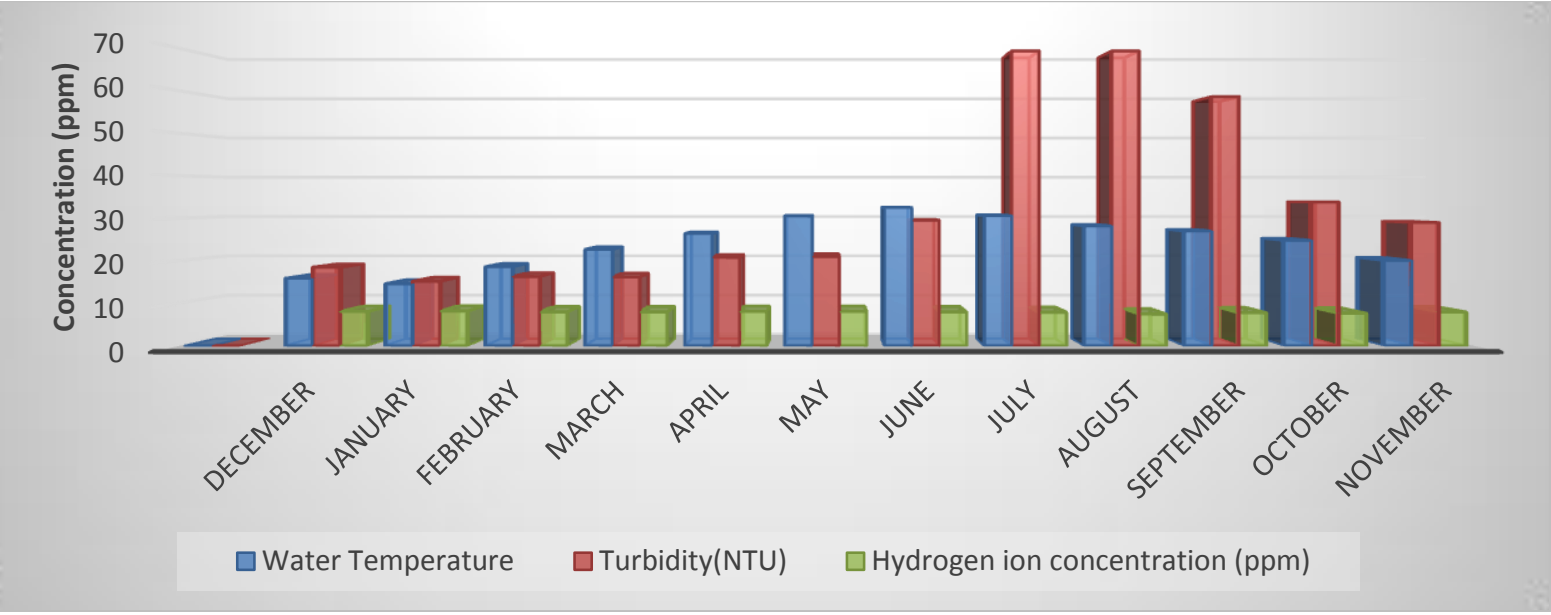

pH: pH of pond varied from 7.5 to 8.2 (Table-A, Graph-1). The lower value of $\mathrm{pH}$ was recorded in rainy season (August) which was due to the increase water volume that bring change in level of carbonate while higher $\mathrm{pH}$ was showed in the month of winter (January). $\mathrm{pH}$ shows positive correlation with total alkalinity. A similar confirmatory result was also observed by Nanda and Tiwari (1999). According to Boyd and pillai (1984) better fish production could be possible in pond water with $\mathrm{pH}$ range 6.5 to 9.0 .

\section{Chemical Parameters:-}

\section{Carbonate and Bicarbonate:-}

Carbonate values varies from 6.75 to $16.65 \mathrm{ppm}$ (Table $\mathrm{B}$, Graph 2) which was due to the utilization of $\mathrm{CO}_{2}$ during photosynthesis thus creating the carbonate. A similar results was also observed by George (1961) while bicarbonate value varied from 136.2 to $198.5 \mathrm{ppm}$ (Table B, Graph 2). Bicarbonate increase with addition of animal excreta.

\section{Total alkalinity:-}

Total alkalinity was ranged from 147.2 to $210.4 \mathrm{ppm}$ (Table B, Graph 2). The value of alkalinity was maximum during summer season due to increased bicarbonate in water while minimum values were recorded during winter season due to high photosynthetic rate. This values of alkalinity as favorable for standing crop of the pond. A similar result was also observed by Huzare M.S. (2008) and Mishra et al (2016).

\section{Chloride:-}

The value of chloride ranged from 10 to $43.50 \mathrm{ppm}$ (Table B, Graph 2). Lower value of chloride was recorded in rainy season (August-September) while higher value was recorded in summer season (May). The chloride level depends upon the level of water bodies. Swarnalatha and Narsingrao (1998) also reported similar trend.

Table B:- Monthly recorded chemical parameters in Keerat Sagar pond (2002-2003)

\begin{tabular}{|c|c|c|c|c|c|c|}
\hline Month & $\begin{array}{c}\text { Carbonate } \\
(\mathrm{ppm})\end{array}$ & $\begin{array}{c}\text { Bicarbonate } \\
(\mathrm{ppm})\end{array}$ & $\begin{array}{c}\text { Total } \\
\text { Alkanity(ppm) }\end{array}$ & $\begin{array}{c}\text { Chloride } \\
(\mathrm{ppm})\end{array}$ & $\begin{array}{c}\text { Dissolved } \\
\text { oxygen }(\mathrm{ppm})\end{array}$ & $\begin{array}{c}\text { Free } \mathrm{CO}_{2} \\
(\mathrm{ppm})\end{array}$ \\
\hline Dec & 16.65 & 142.7 & 147.2 & 19.50 & 8.00 & 15.50 \\
\hline Jan & 15.80 & 145.4 & 161.2 & 28.40 & 8.40 & 11.10 \\
\hline Feb & 14.50 & 152.5 & 167.0 & 31.00 & 7.16 & 10.90 \\
\hline Mar & 13.00 & 158.1 & 171.1 & 36.50 & 6.35 & 14.90 \\
\hline Apr & 10.00 & 175.2 & 185.2 & 25.00 & 5.20 & 15.80 \\
\hline May & 6.75 & 176.5 & 183.3 & 43.50 & 4.56 & 19.80 \\
\hline June & 9.80 & 188.6 & 210.4 & 43.10 & 3.75 & 20.90 \\
\hline July & 10.50 & 198.5 & 200.7 & 36.00 & 5.00 & 19.80 \\
\hline Aug & 9.70 & 186.2 & 195.9 & 10.00 & 6.50 & 18.10 \\
\hline Sep & 7.50 & 155.9 & 163.4 & 10.00 & 6.85 & 17.80 \\
\hline Oct & 7.00 & 145.5 & 152.5 & 24.50 & 7.00 & 13.20 \\
\hline Nov & 10.00 & 136.2 & 148.4 & 34.20 & 8.05 & 22.90 \\
\hline
\end{tabular}


Graph 2:- Monthly Variations in Chemical Parameters

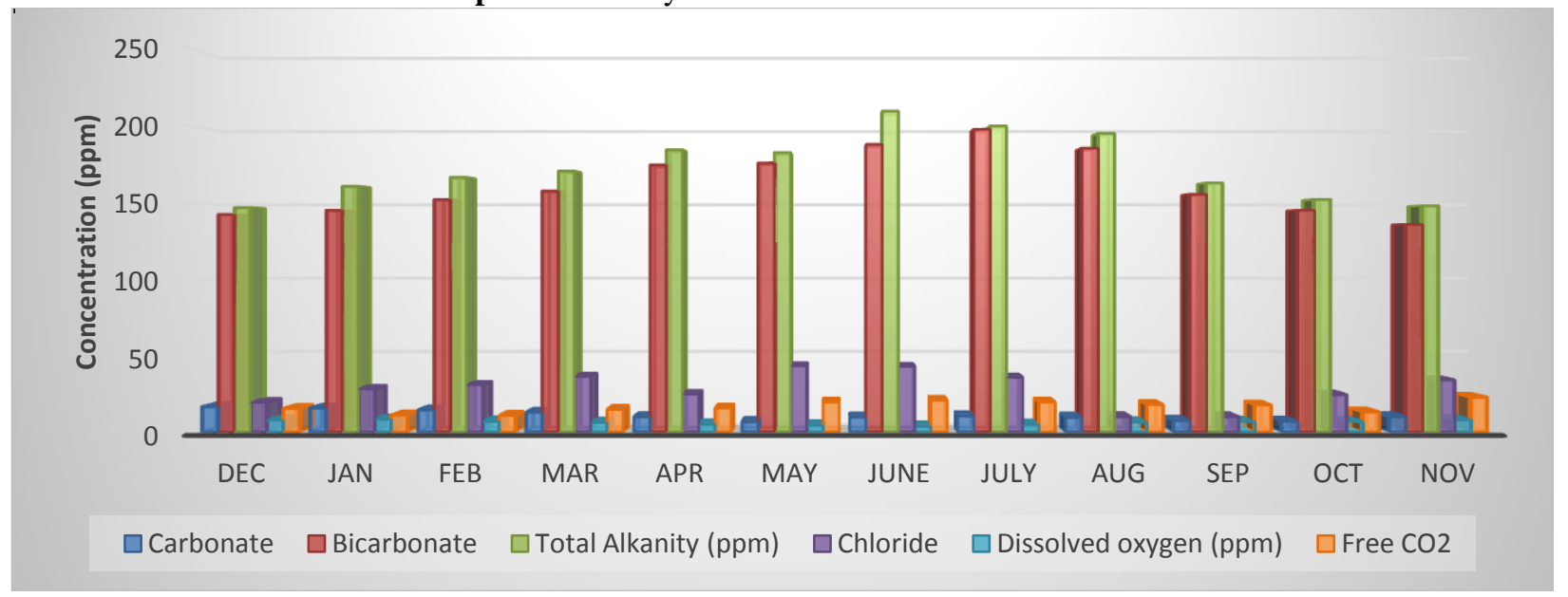

\section{Dissolved Oxygen (DO):-}

The value of DO varied from 3.75 to $8.40 \mathrm{ppm}$ (Table B, Graph 2). Higher DO was found in winter while lower in summer season. The lower value observed as a result of increased runoff agricultural wastes and industrial effluents discharged that places high demand of DO. Similar result was also observed by Krishnamurthy, R. et al (1990).

\section{Free Carbon di-oxide:-}

It was ranged from 10.90 to $22.90 \mathrm{ppm}$ (Table B, Graph 2). Higher value was recorded in the month of November and lower value was recorded in the month of February. This may be depends upon the alkalinity and hardness of water pond. This record was also coinciding with Shimpi, B. et al (2011).

\section{Conclusion:-}

From all the above discussed various Physico-chemical parameters of Keerat Sagar pond it is concluded that there were no drastic variations in aquatic parameters and all these parameters are within permissible and acceptable range hence the environment of pond was found healthy and suitable for the purpose of fisheries, Prawn and Shrimps culture as well as various others aquatic faunal activities.

\section{References:-}

1. Anand, S.B and Bhatt, S.B.2014.Physico-chemical analysis of three different water bodies of sub-tropical Himalayan region of India, Elixir Appl. Bot. 75, p.27712-27715.

2. Ajmal, M., Razi Uddin and Ahsan Ulah Khan. 1988. Heavy metals in water, sediments, plants and fish of Kali Nadi U.P. India. Environ. Int., 14, p.515- 523.

3. APHA 2005. Standard methods for the examination of water and waste water, $21^{\text {st }}$ Edi. Washington, D.C.

4. Boyd, C.E. and Pillai, V.K.1984.Water Quality management in Aquaculture. CIMFRI Spl pub. (22)1-96.

5. Darapu, S.S.K., Sudhakar, B., Ramakrishna, K.S., Rao, P.V., Shekhar, M.C.2011.Determining water quality index for the evalution of water quality index of river Godavari, Int. J.Eng. Res and App., 1 (2), p174 182.

6. Ekpo, B.O. and U.J. Ibok.1999.Temporal variation and distribution of trace metals in freshwater and fish from Calabar river, S. E. Nigeria. Environ. Geochem. Hlth., (21) p51-66.

7. George, M.G.1961.Observations on the rotifers from shallow ponds in Delhi, Curr. Sci. p.268-269.

8. Huzare,M.S. 2008.Seasonal variation of Physico-chemical parameters in the perennial tank Talsande, Maharastra. Ecotoxicol.Environ.Monit, 18 (3) p.233-242

9. Jain and Jain.2007. Engineering Chemistry, $15^{\mathrm{TH}}$ Edition, Dhanpat Rai Publishing Company, New Delhi.

10. Krishnamurthy, R.1990. Hydrobiological studies of wohar reservoir Aurangabad, Maharastra state, India.J. Environ.Biol. 11(3), Hydrobiological studies of wohar reservoir Aurangabad, Maharastra state, India.J. Environ.Biol. 11(3), p.335-343.

11. Kodarkar M.S.1992.Methodology for water analysis, Physico-chemical, Biological and microbiological Indian Association of Aquatic Biologists, Hyderabad, 2, p.50.

12. Mishra, U.K., Narayan, A., Kumar, P.2016.Water analysis of Physico-chemical parameters from sajnam Dam/ Reservoir District Lalitpur U.P. India; Asian J. of Ag. and Life. Sci., Vol 1 (2) p.1-4. 
13. Nanda, S.N. and Tiwari,T.N.1999.Effect of discharge of effluents on the quality of the river Brahmani at Raurkela. Ind. J.Env. Protec.13(1) p.52-55.

14. Simpi, B., Hiremath, S.M., Murthy, KNS., Chandrashekharappa, K.N. Patel, A.N., Puttiah, E.T. 2011. Analysis of water quality using Physico-Chemical Parameters Hosahalli Tank in Shimoga District, Karnataka, India, Global Journal of Science and Frontier Research, 11 (3), p.30-34.

15. Swaranlatha, S. and A. Narsingrao.1998.Ecological studies of Banjara lake with reference to water pollution. J. Envi. Biol.19(2): p.179-186.

16. Thirupathaiah, M. Chaudhary, S. Sammaiah C.2012.Analysis of wter quality using Physico-chemical parameters in lower manair reservoir of Karimnagar district, Andhra Pradesh, International journal of Environmental Science, 3 (1); p.172-180.

17. Trivedi, R.K and Goel, P.K.1986.Chemical and Biological methods for water pollution, Environmental Publication, Karad, Maharastra.

18. Venkatesharaju K., RaviKumar.P., Somashekar.R.K., Prakash. K.L.2010. Physico-chemical and Bacteriological investigation on the river Cauvery of Kollegl Stretch in Karnataka, Journal of Science Engineering and technology, 6 (1) p.50-59. 